\title{
Ways of Improving the Park "Pribrezhny" In Naberezhnye Chelny \\ ${ }^{1}$ Elvira G. Nabeeva, ${ }^{2}$ Renat I. Zamaletdinov, ${ }^{3}$ Maria A. Koshman, ${ }^{4}$ Rais I. Nizamov, ${ }^{5}$ Rinat R. Mingaliev \\ 1, 2, 3, 4, 5 Kazan Federal University \\ Email: i.ricinus@ rambler.ru
}

\author{
Received: 15th December 2017, Accepted: 20th December 2017, Published: 31st December 2017
}

\begin{abstract}
Urbanization is associated not only with the growth of cities, but also with the development of their separate functional zones. This article is devoted to the possible ways of improving the city park "Pribrezhny" in Naberezhnye Chelny. Currently, the park "Pribrezhny" is one of the most important and largest natural objects of Naberezhnye Chelny; one of the cores for the development of city's ecological framework. The authors propose a number of special measures, aimed at improving the park "Pribrezhny". The implementation of these measures will ensure the improvement of the quality of physical, sanitary and hygienic, and visual-aesthetic comfort of the environment, with a commitment to maintaining the ecological balance; and this, in turn, will raise the general standard of living of the population. Preservation and ecological improvement of the park "Pribrezhny" will allow to design and successfully implement the ecological framework of Naberezhnye Chelny, and to ensure sustainable development of the entire urban area.
\end{abstract}

Keywords: Urbanization, Monocities, Ecological Framework, Designing, Park "Pribrezhny".

\section{Introduction}

The development of civilization is associated with the rapid growth of urban areas. This process is accompanied by the development of large cities with a parallel increase in environmental pollution near industrial and manufacturing centers, as well as the deterioration of the quality of life in regions beyond their borders [1].

At present, the network of urban settlements is formed in Russia. The territorial location of these cities and their functions were created under the influence of a combination of factors. Such factors are often called natural and climatic conditions. In some cases, the formation of cities is also conditioned by their narrow specialization, which is dictated by the role for the development of the country. Such cities are called monotowns.

At present, monotowns are one of the main elements of the cities network in Russia. So today, there are more than 900 city-forming enterprises in the monocities, which produce almost $30 \%$ of the country's total industrial output.
As follows from the data of the scientific and methodological center "Goroda Rossii", at least 500 out of 1097 cities are classified as monocities that is $45.6 \%$ of the total number of Russian cities [2]. Naberezhnye Chelny is a monocity, which was created as an industrial site for the production of heavy trucks.

As in other monocities of Russia, the problem of social well-being of the population is especially acute in Naberezhnye Chelny. It is known, that in large monotowns, social welfare decreases with the increase of city growth, and its growth rate.

Often, the high rate of cities growth does not allow to take full measures of social reorganization, accomplished through the planning and development of urban areas. All these measures should be aimed at increasing the attractiveness of the environment for human.

The main architectural and town-planning means for improving the environmental conditions of living in industrial cities are the following: the creation of corridors for the ventilation of urban areas; rational landscaping of sanitary protection zones; the increase in the level of greenery of urban areas; the creation of developed water and green systems of cities. The adoption of these measures contributes to the reduction of social tension [3].

Territorial development of the city's natural framework, its natural surroundings is achieved by the increasing of green spaces network, extended elements of this system - greened footpaths, walking paths, bicycle trails with their territorial reference to specially protected natural areas. Also, it is achieved with the formation of ecological "axes", taking into account the landscape dominants, the creation of guard plots, special structure of plantings, as well as water protection zones along the banks of rivers and reservoirs.

The implementation of ecological approach in city development is fully realized when planning and designing city parks. Parks play an important role in the development of the city's ecological framework. City parks are necessary to create conditions for active and meaningful recreation of the city's residents. Also, urban parks are the essential elements for the conservation of biological diversity [5] and the components of ecological framework. The park "Pribrezhny" in Naberezhnye Chelny is an integral part of life and favorable development of the 
city. This article is the result of the development of measures for the advanced ecological improvement of the park's territory.

The work was carried out at the Department of Environmental Engineering and Water Management of the Institute of Management, Economics and Finance of Kazan (Volga region) Federal University.

\section{Material and Methods}

The material for the present work was the file materials of the Mayor's Office of Naberezhnye Chelny, maps, schemes of the urban area, as well as the results of field research, carried out in 20162017.

Google Earth data for 2006-2017 were used to obtain satellite images. These images were used to obtain the following data:

1. Topographic framework for the site plan in the project part.

2. Tracking the dynamics of changes in the territory of the park "Pribrezhny".

3. Specifying the objects, located in the park.

Photo fixation of the territory of park "Pribrezhny" was performed on site. When creating the project for the improvement of park "Pribrezhny", the following graphic programs were used: Corel DRAW X7 and SketchUp.

The project for the improvement of the park "Pribrezhny" was formed taking into account the following investigations: the location of the facility in Naberezhnye Chelny; the analysis of the object, using space images of different years; location of the object on the public cadastral map; scheme of urban development zoning; current use of the territory; scheme of transport infrastructure of Naberezhnye Chelny; road-and-path network (existing); the analysis of the existing infrastructure of the projected territory; scheme of the natural-ecological framework of Naberezhnye Chelny; the scheme for the integrated assessment of the territory, based on natural-anthropogenic indicators; the analysis of flora and fauna; general characteristics of the lake "Lesnoe"; photographic fixation; general plan of the project for the improvement of the park "Pribrezhny" in Naberezhnye Chelny; visualization; general view.

\section{Results and Discussion}

Naberezhnye Chelny is a city in the Russian Federation, located in the north-eastern part of the Republic of Tatarstan, on the left bank of the Kama River. The city is characterized by a flat relief, temperate continental climate, with cold winters and warm summers; in terms of the amount of precipitation it refers to the zone of insufficient moisture.

The main structural elements of the greening system of the city and the suburban area have a significant multi-faceted impact on the state of the environment. They sustain the course of natural biosphere processes, have the climate-controlling influence, reduce anthropogenic impact on the environment, contribute to an integrated balanced use of natural resources, improving the conditions for economic activity, residence and recreation of population.

The general condition of green plantations of the city is estimated as weakened - greatly weakened. In fact, it is necessary to carry out a complex of agro technical measures for each large object of gardening.

Based on the above, we can conclude, that it is necessary to expand the network of green spaces (city parks, squares, boulevards) in Naberezhnye Chelny.

The main structural elements of the greening system of the city and the suburban area sustain the course of natural biosphere processes, have the climatecontrolling influence, reduce anthropogenic impact on the environment, contribute to an integrated balanced use of natural resources, improving the conditions for economic activity, residence and recreation of population.

In the structure of natural-ecological framework of Naberezhnye Chelny, there are the following territorial units, which differ in the specific of the performed environmental functions: the core; other key areas; ecological corridors (natural, naturalanthropogenic and anthropogenic); buffer zones.

In accordance with the location, it can be said, that the park "Pribrezhny" is the core in the structure of the city's natural-ecological framework (Figure 1).

Being the core, the park performs various functions, namely: water regulating, environment-forming, as well as conservation, reproduction of biological resources and conservation of biodiversity. In addition, it ensures the sustainability of the natural environment.

The analysis of the existing situation of the naturalecological framework showed, that green zones on the territory of the city do not have a definite system in location. We can say that green plantations, being the buffer zones, are located in a chaotic order. They are connected with each other, but they are not connected with the core - the park "Pribrezhny". This structure negatively affects the city, since there is no "communication" between the zones. 


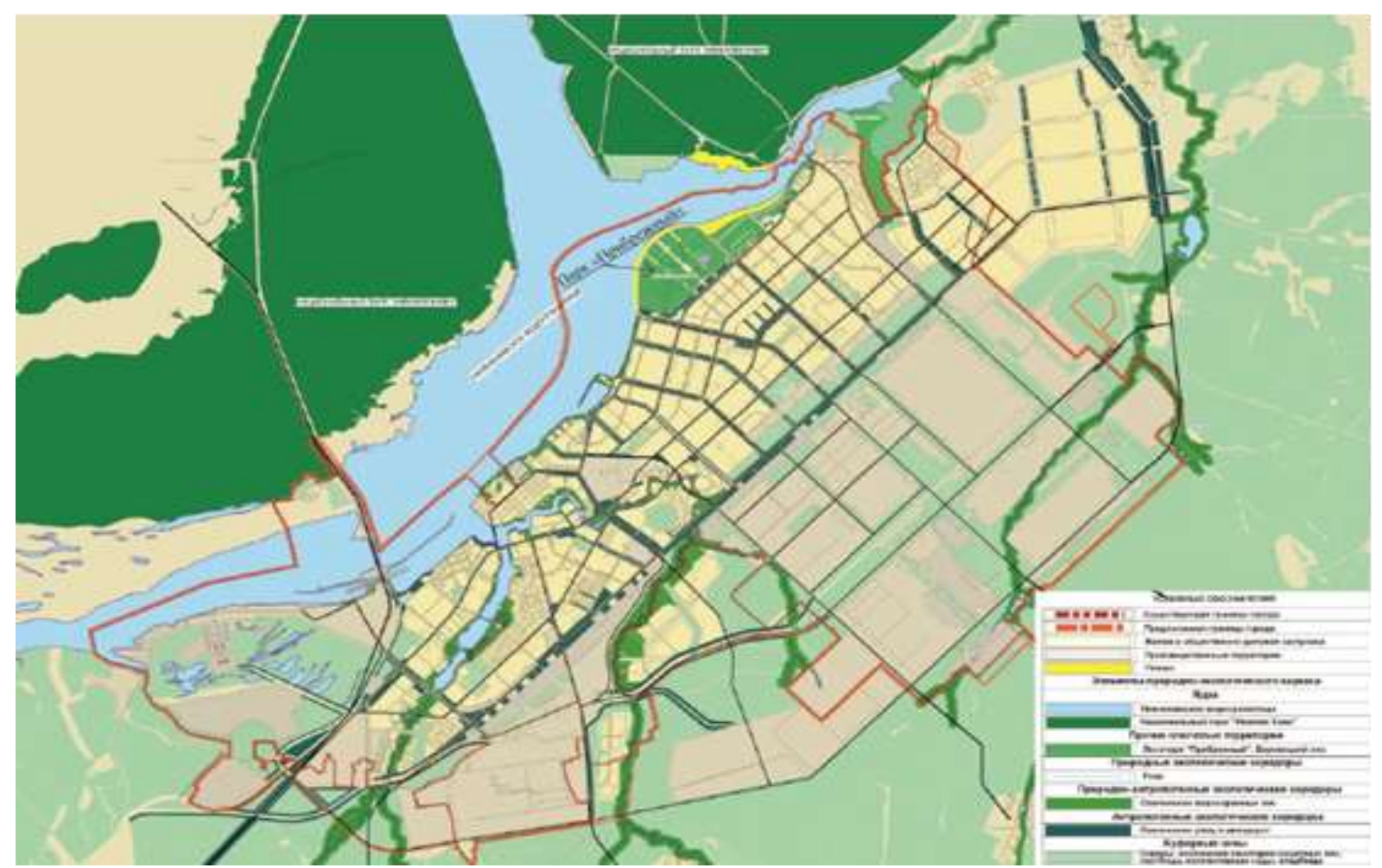

Figure 1. Scheme Map of the Natural-Ecological Framework of Naberezhnye Chelny

To solve this problem, it is necessary to connect the buffer zones with the core of the natural-ecological framework, to create ecological corridors. They will allow to connect separate elements of the ecological framework of the city and, thereby, to create a certain structure of green spaces.

The creation of urban parks is associated with the need for routine activities, aimed to preserving and developing of ecological and aesthetic qualities. According to the research of Gorzelenhoz, forest plantations in the park "Pribrezhny" have the following characteristics: composition - 10C, height class - III, height - $16 \mathrm{~m}$, trunk diameter at a height of $1.3 \mathrm{~m}-16 \mathrm{~cm}$, stand density -1.0 . The physical state of tree species is characterized as weakened and greatly weakened. According to the scale of categories of tree states, their values can be determined as 2 and 3, respectively. Recommended measures for the conservation of natural objects are the following: sanitary felling, improvement cutting, complex of sanitary protection measures against pests and diseases, including pine fungus, plantation of deciduous trees and bushes, landscaping.

Currently, all pine plantations in the city, including in the forest park "Pribrezhny" are in the third grade of age, from 40 to 60 years, that is, in the period of thinning. At that time, another $25 \%$ of trees die and should be cut down. That is by the time of transition to class 4 (age 60-80 years), only 2000-2500 pieces of trees should remain, and by the time of ripeness ( 80 years) - only 300 pieces, with a distance between trees of 5-6 meters. This law of nature also operates in urban pine plantations. Due to this, there are so many dry and fallen trees in places where felling is not carried out [8].

The park "Pribrezhny" was founded in the 1950s within the city of Naberezhnye Chelny. The area of the park is 265.2 hectares. The park "Pribrezhny" is located in the coastal strip of Nizhnekamsk Reservoir, in the northwestern part of the micro district "New City", near the prospect "Chulman". The northern part of the park is next to Nizhnekamsk reservoir, and the southern, western and eastern adjacent to the city.

According to the analysis of the site location, using the Public cadastral map of Naberezhnye Chelny, the land category of the design area - is the land of settlements. The number of cadastral quarter of the design area is 16:52:0000000.

According to the scheme of urban development zoning, the park "Pribrezhny" is located within the urban development zone P-1 (the zone of recreational and landscape territories), it borders with the zones G-4 (low-rise (3-5 floors) mixed residential development zone), G-5 (mid-rise (9 floors and more) residential development zone) and G-1 (zone of individual estate residential development).

Currently, different objects, such as: sports, administrative, cultural and entertainment, sports and recreation facilities, are located in the park "Pribrezhny".

The sports facilities, placed on the territory of the park "Pribrezhny" include: "Tulpar" - children's and 
youth equestrian school named after R.S. Khamadeev; "Navigator" - youth athletic center of yachting sport; boating station "Mayak"; the racetrack. These objects are owned by public-legal entities [7].

Cultural and entertainment facilities, located on the territory of the park "Pribrezhny" include: The Palace of Celebrations, "Maidan" (the venue for public holidays), "DUBAI" - the restaurant, "Divar" -the banquet hall. The Palace of Celebrations is owned by public-legal entities. The restaurant "DUBAI" and the banquet hall "Divar" are privately owned. Data, on the form of ownership of the object "Maidan" is not available. Sports and health club "Planeta Fitness", located in the park "Pribrezhny", refers to the sports and recreational type of structures. "Planeta Fitness" is owned by publiclegal entities.

Field investigations of 2016-2017 showed, that the animal world of the park "Pribrezhny" does not differ in a special variety. In this territory birds are characterized by their large number, in comparison with other inhabitants of the park.

The vegetative world of the park is characterized by coniferous and deciduous species. Most of the park is occupied by coniferous species - pine (Pínus sylvéstris). Deciduous species, such as white willow (Sálix álba), weeping birch (Betula pendula), are mainly located near the lake "Lesnoe" and in the north-eastern part of the park.

According to the scheme of modern use of the territory, a functional zoning scheme was drawn up. This territory consists of 4 zones. The first zone - the territory of residential development, the $2^{\text {nd }}$ zone public and business area, the $3^{\text {rd }}$ zone -the lake "Lesnoe" and the $4^{\text {th }}$ zone - recreational area.

The project for the improvement of the park "Pribrezhny" in Naberezhnye Chelny provides for the division of the park into three parts: City Boulevard, forest park, and coastal zone.

City Boulevard-is the southern part of the park. There is a public zone; city events are held there. In this territory it is planned to perform works on improvement and creation of a sports and leisure zone.

The forest park is the middle part of the park. In this part the residents of the city can find a place for seclusion with nature. The project provides for the improvement of the lake "Lesnoe".

The coastal zone -is a shoreline. In this part of the park the residents of the city can get in touch with water. The project of the improvement proposes to allocate there two zones: wild and promenade water areas.

The allocation of the part of coastal area to preserve the natural conditions of life of the park inhabitants is supposed in the wild zone.

The water promenade zone provides for the creation of environmentally friendly paths over the surface of the water, to ensure the access of the city residents to water and to improve the coastal zone.

In the area of city boulevard it is proposed to place a sports-leisure and cultural-leisure zone. In the sports and leisure zone it is proposed to arrange a rental center of sports equipment (by season), cynological kennel club and a territory for workout. In the cultural and recreational zone, it is proposed to create an alley of newlyweds.

In the second zone (forest park), the measures for the improvement of the forest park area are proposed. Near the lake "Lesnoe" there is a track with a wooden covering. An organized road-and-track network will ensure fast and comfortable movement through the park. In the places of people's congestion, it is proposed to create special territories with a fast food service area.

2 zones - wild and promenade water areas are allocated within the territory of the third zone (coastal zone). The entrance on the territory of the wild zone is forbidden for the people. There are the signs with explanations. On the territory of the promenade water area, there are three piers, made of environmentally friendly material, above the surface of the water.

\section{Summary}

On the basis of our investigation, we can draw the following conclusions:

1. The park "Pribrezhny", being the core of the natural and ecological framework of the city, ensures the preservation of biological diversity, and also supports the sustainability of the natural environment of Naberezhnye Chelny.

2. In the project for ecological improvement of the park "Pribrezhny" it was proposed to allocate three zones within the park area (city boulevard, forest park and coastal area), and the measures for their improvement were offered.

3. Functional zoning of the forest park territory allowed to allocate zones for preserving the habitats of wild birds and animals.

\section{Conclusion}

Parks in the city, as well as other green areas, are under the influence of various negative factors. The consequence of anthropogenic influence is industrial, household and trucking pollution. As a result, the processes in biogeocenosis, the structure and functioning of park are changing negatively.

All green zones experience anthropogenic pressure, so it is very important to monitor their condition and, if necessary, to carry out restorative measures.

The sustainable development of the territory to a large extent depends on the state of the natural resource potential and the ecological state of natural sites. So, the formation of natural and ecological framework of settlements is an urgent task. 
Summarizing, it can be said, that the park "Pribrezhny" is one of the most important and largest natural sites in Naberezhnye Chelny. So, it is important to preserve and to improve its quality characteristics, as the core of the city's natural and ecological framework.

At the moment, the park "Pribrezhny" is one of the most favorite places of the townspeople, where residents can connect with nature, find the opportunity to enjoy clean air, seclude from the hustle and bustle of the city. All this improves the quality of life in the city, especially taking into account the fact, that Naberezhnye Chelny is one of the monocities (industrial cities) in the Russian Federation.

Activities, aimed at improving the park "Pribrezhny" will ensure the improvement of the quality of physical, sanitary and hygienic, and visual-aesthetic comfort of the environment, with the commitment to maintaining a relative ecological balance; and this, in turn, will raise the general standard of living of the population. Therefore, the improvement of the park "Pribrezhny", is an important task for the city.

\section{Acknowledgements}

The work is performed according to the Russian Government Program of Competitive Growth of Kazan Federal University.

\section{References}

1. López Estrada R.E. Crisis of the urban development process and the ecological, economic and social sustainability // Contexto. Vol. X. № 12, Marzo 2016. - Pp. 39-47.

2. Uskova T.V., Iogman L.G., Tkachuk S.N., Nesterov A.N., LitvinovaN.Yu. Monotown: development management. Vologda, 2012.

3. Potaev G.A. Ecological renovation of cities. Minsk: BNTU, 2009 - 173 p.

4. Laghai H., Gilani S.M. Planning and Design of Urban Sustainable Riparian Park (Case Study: Kan River-Valley) // International Journal of Architecture and Urban Development. Vol.4, No.3, Summer 2014. - Pp. 19-30.

5. Zamaletdinov R.I., Mingaliev R.R., Kiseleva A.A. The Terrestrial Vertebrate Fauna of Valuable Natural Areas in Kazan // Research Journal of Pharmaceutical, Biological and Chemical Sciences. 2016. Vol. 7. № 6.- Pp. 2850-2855.

6. Floristic description of the park "Pribrezhny", 2015. http://euroasia-science.ru/biologicheskienauki/floristicheskoe-opisanie-parkapribrezhnyj/\#sthash.bsYVnh0J.dpuf.
7. Federal Service for State Registration, Cadastral Records and Cartography. https://pkk5.rosreestr.ru/\#x=11554711.454933215 $\& y=10055441.599232892 \& z=3$.

8. OAO "Gorzelenhoz", Naberezhnye Chelny. http://gorzelenhoz-nch.ru/. 